Bada, A. A., \& Jita, L. C. E-Learning Facilities for Teaching

Secondary School Physics: Awareness, Availability and Utilization

\title{
E-Learning Facilities for Teaching Secondary School Physics: Awareness, Availability and Utilization
}

\author{
Abiodun A. Bada*1 \& Loyiso C. Jita ${ }^{1}$ \\ *Corresponding Author: Bada.AA@ufs.ac.za \\ 1. Faculty of Education, University of the Free State, South Africa \\ Received : 2021-10-13 \\ Revised : 2021-11-22 \\ Accepted : 2021-12-10 \\ $10.46303 /$ ressat. 2021.40
}

\begin{abstract}
How to cite this paper: Bada, A. A., \& Jita, L. C. (2021). E-Learning Facilities for Teaching Secondary School Physics: Awareness, Availability and Utilization. Research in Social Sciences and Technology, 6(3), 227-241. https://doi.org/10.46303/ressat.2021.40

This is an Open Access article distributed under the terms of the Creative Commons Attribution 4.0 International license (https://creativecommons.org/licenses/by/4.0/).
\end{abstract}

\section{Abstract}

Secondary school physics contribute significantly to the technological development of a nation because it lays the foundation for further studies in physics. Physics is an abstract science subject that relies greatly on practical, and the crucial role played by the use of instructional materials especially, e-learning facilities in this 21 st century cannot be over emphasized. This study investigates the awareness, availability and utilization of e-learning facilities among secondary school physics teachers. We adopt the descriptive survey design which involved 78 physics teachers, randomly selected from all the secondary schools in Ondo, Nigeria. A researcher designed checklist was used to collect data for this study. Three research questions were answered using descriptive statistics (frequency, percentage, mean, standard deviation) and the findings from this investigation revealed that physics teachers are aware of most of the e-learning facilities for teaching secondary school physics but only few of these facilities are readily available for teaching physics. This investigation also revealed that only one of these elearning facilities (desktop computer) was utilized by secondary school physics teachers. This study conclude that e-learning facilities were not used in teaching secondary school physics in Ondo. Based on these findings, physics teachers are encouraged to use the few e-learning facilities that are available in secondary schools. Also, government education agencies and school management team are encouraged to further stress the importance of using the available e-learning facilities for teaching secondary school physics through in-service trainings and workshops.

Keywords: Availability; awareness; e-learning facilities; utilization; secondary school physics 
Bada, A. A., \& Jita, L. C. E-Learning Facilities for Teaching

Secondary School Physics: Awareness, Availability and Utilization

\section{Introduction}

The study of physics and its application is crucial to the technological development of any nation. However, the adequate teaching of physics at the secondary school has been threatened by disruptions, such as the covid-19 pandemic, which has forced most nations of the world to observe lock down in order to prevent the continuous spread of the highly deadly virus. The effect of this disruption is capable of frustrating the achievement of the objectives of the secondary school physics curriculum. The adverse effect of these disruptions can be alleviated through the use of technology in education because, technology today has turned the world to a global village (Oluwalola \& Awodiji, 2019). Not only is the use of technology effective at alleviating the problems of educational disruptions, but it has also provided instructional materials that assist in achieving these objectives with ease and less stress. Instructional materials in education context are materials that assist in passing instructions in the classroom. The use of these instructional materials also eases the stress of having to explain and re-explain, thus, making teachers and students to struggle less in the classroom.

Technology has provided a range of opportunities to leverage and overcome many of the challenges brought by physical disruption in education (Tarman et al., 2019). Halim et al (2020) argue that the development of education is inseparable from the development of science and technology. Skhephe and Matashu (2021) further opine that "technology has provided a lot of information in this 21st century than any one person could ever hope to acquire" (p. 268). Akanbi (2020) also argue that "technology has become one of the best means for enhancing teaching and learning with or without school premises" (p. 332). This situation presents an advantage over the traditional lecture method otherwise known as face-to-face teaching method, which can be easily disrupted by incessant strike actions, natural disaster, and pandemics such as the covid-19 pandemic. According to Shelly et al (2012), "technology can provide the right channel for teachers to nurture higher level thinking in students, especially in the formation of $21^{\text {st }}$ century skills" (p. 211). The advent and use of computer assisted instruction (CAI), which is an integral part of technology in education, further attest to the fact that technology in education paves way for development and better innovations.

Ramma et al (2018) opined that "technology in education is used as a source of information rather than a process based on knowledge construction" (211). This implies that the dividends brought by technology to teaching and learning can be improved on by leveraging fully on its products. For example, Kopish and Marques (2020) opine that "increase of technology has further brought to reality the possibility of having collaborative work between institutions in different countries" (p. 1). It also allows learners to take a more active role in their learning through the use of different instructional modes. Akubueze (2012) argue that "technology encouraged active learning, support teaching, reduce the isolation of teachers and promotes teachers and students in learning and research" (p. 347). Ohlin (2019) opine that "technology has made it possible to view the world through a digital lens, and teachers can access this knowledge at will via interactive smartboards (touch boards), or students' laptops and touchpads/ipads" (p. 43). An important product that technology and CAl has brought with it is the development of e-learning facilities. This can further assist in maximizing the benefits that comes with the use of technology in education. 
Electronic learning, otherwise referred to as e-learning was developed by Jay Cross in 1998 (Ja'ashan, 2020) and it has continued to metamorphosed up till date. Zhang et al (2004) define "e-learning as technology-based learning in which learning materials are delivered electronically to remote learners via a computer network" (p. 76). According to Mayadas et al (2009), "the benefits that come with the use of e-learning is that it widens access to education and offers opportunities for pedagogical improvement by instructors" (p. 86). O'Brien (2020) opine that "e-learning may be advantageous for physics teaching especially through the use of smartphone, online systems and social medias" (p. 404). This is so because many of these facilities helps to project the adequate teaching and learning of physics in the classrooms. Akanbi (2020) argue that "e-learning is the process of teaching and learning with the use of computer via the internet" (p. 331). In what looks like a support for this assertion, Oluwalola and Awodeji (2019) opine that "e-learning facilities provide productive teaching and learning experiences aimed at increasing capability in management and business course in tertiary institutions" (p. 347). Ja'ashan (2020) therefore argue that "e-learning provides a new paradigm and a modern philosophy in teaching with a mission to serve as a development platform from the present day society based on knowledge" (p. 128).

E-learning facilities provide the opportunity to leverage on the breakthrough that comes with using technology in education. Alabi et al (2012) define e-learning as a "unifying term used to describe the fields of online learning, web-based training and technology delivered instructions" (p. 70). Rosenberg (2001) views e-learning as "the appropriate application of the internet to support the delivery of skills and knowledge in a holistic approach not restricted to a particular course, technology or infrastructure" (p. 1). According to Garrison (2011), "e-learning is an electronically mediated asynchronous and synchronous communication to construct and confirm knowledge" (p. 2). In this present study, we define e-learning facilities as all those facilities that are connected one-way or the other to the use of technology, to foster effective teaching and learning either in the school or outside the school. E-learning facilities include all electronically powered devices that can assist in ditching out the curriculum content in bits in order to achieve classroom goals and objectives.

Previous studies on e-learning and its effects on students' achievement reveal that there is positive impact of its use in education. In Tanzania for example, Innocent and Masue (2020) investigated the "applicability of e-learning on higher learning institutions" (p. 242) and found out that the strong enforcement of an information communication technology (ICT) institution policy, well equipped classroom ICT facilities and availability of technical experts are among the strategies to ensure effective application of e-learning in higher learning institutions. O'Brien (2020) in the United State of America, investigated how to incorporate e-teaching of physics in a post-covid world, by identifying the benefits, barriers and key factors required for its implementation. The researcher discovered that smartphones, which is an important type of e-learning facility can be successfully converted into a learning tool when allowed by teachers. Ja'ashan (2020) in his study in Saudi Arabia investigated "the challenges and prospects of using e-learning among EFL students in Bisha University" (p. 124) and found out that despite the benefit that e-learning can be used anywhere and anytime, it is currently being faced with the inability to predict academic achievements by all the domains of teaching staff and students. This suggest that academic staff who are responsible for the use of e-learning facilities lack the 
necessary awareness regarding the integration of software into teaching. Oluwalola and Awodiji (2019) also investigated the "availability and utilization of e-learning facilities for management and business courses in universities in kwara state" (p. 346) and discovered that e-learning facilities are moderately available in the sampled universities

In Nigeria, Fayomi et al (2015) examine the "impact of e-learning in facilitating students' performance among private secondary schools and tertiary institutions in Ota" and found out that "e-learning facilitated studies significantly improved students' academic performance, learning process and self-development" (p. 5). They also argue that "e-learning provide an effective means for self-development and facilitates secondary schools and tertiary institutions academic performance" (Fayomi et al, 2015, p. 6). Eze et al (2018) investigated the "utilization of e-learning facilities in the education system of a university" (p. 1). Their study adopted the qualitative approach which involved 65 participants to investigate the utilization of e-learning facilities and found out that e-learning facilities were adequate, available and well utilized by teachers in the sampled university. In another study, Eze et al (2020) investigated the "factors influencing the use of e-learning facilities by students in private universities" (p. 1) and noted the degree of engagement of the use of e-learning facilities. The researchers conclude that the use of e-learning in this institution is still not encouraging.

Literature reveals that a number of studies have been carried out on the extent of availability and the utilization of e-learning facilities in secondary schools in Nigeria. Samba et al (2010) investigated "science teachers' awareness and utilization of teaching strategies in secondary schools" (p. 32) and found out that many innovative strategies including computer assisted instruction (CAI) were not utilized for teaching science subjects. Sambal et al (2010) adopted the descriptive survey design involving 160 science teachers to obtain information on science teachers' awareness and utilization for innovative teaching and found out that science teachers have not been using modern teaching methods in the classrooms. In another study, Ramma et al (2018) used a qualitative approach to investigate the use of technology to teach and learn physics. They investigated the extent to which technology mediated the interaction among parents, students and teachers. The researchers found out that technology moderated collaboration among physics teachers, students and parents within the context of motivation, interest and values.

In a more recent study by Akanbi (2020) on the" availability and utilization of e-learning facilities in the teaching of senior secondary school physics in llorin" (p. 331), the researcher found out that almost all the e-learning facilities identified in the study were inadequate and those available were not effectively utilized by teachers. Akanbi (2020) conclude that physics teachers should be trained on how to use and maintain e-learning facilities in the various secondary schools. This perhaps suggest that the challenge facing the use of e-learning facilities is that physics teachers are unable to use these facilities.

While the above studies have made contributions on the accessibility and applicability of elearning facilities in the universities (Eze et al, 2018; Eze et al, 2020; Innocent \& Masue, 2020; Ja'ashan, 2020) and secondary schools (Samba et al, 2010; Ramma et al, 2018; Akanbi, 2020), this present investigation is unique in the sense that it first sought to find out the level of 
awareness of these facilities among secondary school physics teachers in Ondo. It later proceeds to investigate its availability and utilization in secondary schools.

This present study argues that despite the key role played by e-learning facilities in improving students' achievement, the problem of inadequate awareness both in research, practice and regards to its availability and utilizations in secondary schools in Ondo is still a gap that need to be filled in literature (Innocent \& Masue, 2020; Akanbi, 2020). This study therefore has three aims: (i) to determine the level of awareness of e-learning facilities among secondary school physics teachers (ii) to determine the e-learning facilities that are available for teaching secondary school physics (iii) to investigate the e-learning facilities that are utilized for teaching secondary school physics.

\section{Research Questions}

In line with the aims of this study, we ask the following research questions:

- What is the level of awareness of e-learning facilities among secondary school physics teachers?

- What e-learning facilities are available for teaching secondary school physics?

- What e-learning facilities are utilized for teaching secondary school physics?

\section{Method}

This study is a quantitative research which adopt the descriptive survey design. Aggarwal and Ranganathan (2019) define descriptive study "as one that is designed to describe the distribution of one or more variables, without regard to any causal or other hypothesis" (p. 34). Nassaji (2015) and Navarro-Patón et al (2020) have used this design in their studies and found it appropriate for describing events without any manipulation. The method used in this study is discussed under the following headings: participants, instrument, procedure for data collection, and data analysis.

\section{Participants}

All the secondary school physics teachers in Ondo, Nigeria represent the population for this study. There are 57 (32 schools in Ondo west local government area, 12 schools in Ondo east local government area, 12 private secondary schools) approved secondary schools in Ondo, Nigeria. Out of this population, only 46 secondary schools participated in this study. The participating schools were selected using simple random sampling technique. The selected sample represent $80.7 \%$ of the total population of secondary school physics teachers in Ondo. A total of 78 physics teachers gave consent and participated in this investigation. The participants were $64(82.0 \%)$ males and 14 (18.0\%) females, and their ages range between 22 and 58 years.

\section{Instrument}

A researcher designed checklist was used for this study. The checklist is titled; awareness, availability and utilization of e-learning facilities for teaching physics. The items that make up the checklist were compiled from the available literature on e-learning facilities that can be used for teaching physics. The final draft of the checklist is made up of three sections. The first section deals with awareness of e-learning facilities that can be used to teach physics among 
secondary school physics teachers. This first section adopt the Likert scale designed on two scales, Aware (A) and Not Aware (NA). The second section provides statement on how accessible these facilities are, and it was designed on a five-point Likert scale comprising Highly Available (HA), Available (A), Moderately Available (MA), Fairly Available (FA), Not Available (NA). The third section focus on the application of these facilities during secondary school physics teaching. This section is also structured on a five-point Likert scale namely, Highly Utilized (HU), Utilized (U), Moderately Utilized (MU), Fairly Utilized (FU). The validity of the instrument was achieved through engagement with three experts in curriculum and instruction, from Adeyemi College of Education Ondo. The experts conducted face and content validation to ensure that the instrument has the capacity to measure what it is designed to measure. The suggestions of the validators were duly accepted and effected before adopting the final draft. The reliability of the checklist was achieved by administering the instrument to five secondary school physics teachers who were not part of the sample used in this study. A reliability coefficient of 0.82 obtained through Cronbach Alpha confirmed that the instrument is consistent and can be trusted to measure what it is designed to measure.

\section{Procedure for Data Collection}

Copies of the checklists were personally administered by the researchers to the participants during 2020 coordination/marking exercise organised by the West African Examination Council for physics examiners in Ondo, Nigeria, after their consent were sought to take part in this study. A total of 78 secondary school physics teachers from 46 secondary schools in Ondo agreed to be part of this study. The administration of the instrument took place after completing day 2 of the coordination exercise. The coordination/marking exercise brings together secondary school physics teachers in Ondo who would serve as examiners for the examination body. The West African Examination Council (WAEC) is an international examination body saddled with the responsibility of conducting senior school certificate examinations in the West African countries of Ghana, Nigeria, Sierra Leone, Gambia and Liberia. All the participants who gave consent completed the checklist and the researchers immediately retrieved the completed checklist.

\section{Data Analysis}

The data collected from this investigation was analysed using descriptive statistics. Microsoft Excel spread sheet package was used in computing the data obtained from the study. Research question one was answered using frequency count and simple percentage while research questions two and three were analysed using mean and standard deviation. Participants responded to the checklist by selecting one option from the range of options already provided in the checklist. The responses from the participants were analysed by allocating values to the options. The following grading system was adopted: Highly Available $(H A)=5$, Available $(A)=4$, Moderately Available $(M A)=3$, Fairly Available $(F A)=2$, Not Available $(N A=1)$. In a similar fashion, Highly Utilized $(H U)=5$, Utilized $(U)=4$, Moderately Utilized (MU) =3, Fairly Utilized (FU) $=2$, Not Utilized $(\mathrm{NU})=1$. The mean and standard deviation value of each of the e-learning facilities were calculated using Microsoft Excel spreadsheet 365. For the decision rule, a mean value less than 2.50 implies that the e-learning facility is not available while a mean value equal or greater than 2.50 implies that the e-learning facility is available. A similar decision rule was adopted for research question three such that, a mean value less than 2.50 implies that the e- 
learning facility is not utilized in the secondary school while a mean value equal or greater than 2.50 implies that the e-learning facility is utilized for teaching physics at the secondary school.

\section{Findings and Discussion}

\section{Research Question 1: What is the level of awareness of e-learning facilities among secondary school physics teachers?}

Table 1 shows the level of awareness of e-learning facilities among physics teachers in secondary schools in Ondo, Nigeria. Table 1 reveals that all the participants were aware of desktop computers, internet facilities/network, laptop computers, local area network, megaphone, memory cards, phones, photocopier machines, printers, scanners, radios, televisions and video tapes, as e-learning facilities that can be used for teaching secondary school physics. More than half of the participants also revealed that they are aware of the following 14 e-learning facilities. This include audio tapes (92.3\%), CD writers (97.4\%), digital camera (97.4\%), e-mails (78.2\%), flash drives (83.3\%), hard disk drives (53.8\%), ipads (88.5\%), modems (93.6\%), podcasting (53.8\%), power point software (74.4\%), projection screen (87.2\%), projectors (83.3\%), video recorders (97.4\%) and wifi $(98.7 \%)$. More than half of the participants were not aware that facilities such as e-book readers (84.6\%), flexible learning toolbox (87.2\%), ilearn (88.5\%), respondus/software (84.6\%), virtual classroom (84.6\%), virtual library (76.9\%) can be used for teaching secondary school physics. The result from this investigation revealed that out of a total number of 36 e-learning facilities that make up the checklist, physics teachers are aware of 27 e-learning facilities (75.0\%). This implies that physics teachers are aware of these e-learning facilities for teaching physics. This result agrees with Sambal et al (2010) who found out that most science teachers especially physics teachers, are aware of computer assisted instruction (CAI) which is an integral part of the use of technology in education. 
Table 1. E-learning awareness among secondary school physics teachers

\begin{tabular}{|c|c|c|c|c|c|}
\hline $\mathrm{S} / \mathrm{N}$ & e-Learning Facilities & $\begin{array}{l}\text { Aware } \\
\text { (n) }\end{array}$ & $\begin{array}{l}\text { Aware } \\
(\%)\end{array}$ & $\begin{array}{l}\text { Not Aware } \\
\text { (n) }\end{array}$ & $\begin{array}{l}\text { Not Aware } \\
(\%)\end{array}$ \\
\hline 1 & Audio tapes & 72 & 92.3 & 6 & 7.7 \\
\hline 2 & CD writer & 76 & 97.4 & 2 & 2.6 \\
\hline 3 & Desktop Computer & 78 & 100.0 & - & - \\
\hline 4 & Digital Camera & 76 & 97.4 & 2 & 2.6 \\
\hline 5 & Emails & 61 & 78.2 & 17 & 21.8 \\
\hline 6 & E-book Readers & 12 & 15.4 & 66 & 84.6 \\
\hline 7 & Flash Drive & 65 & 83.3 & 13 & 16.7 \\
\hline 8 & $\begin{array}{l}\text { Flexible Learning } \\
\text { Toolbox }\end{array}$ & 10 & 12.8 & 68 & 87.2 \\
\hline 9 & Hard Disk Drives & 42 & 53.8 & 36 & 46.2 \\
\hline 10 & $\begin{array}{l}\text { Interactive White } \\
\text { Board }\end{array}$ & 34 & 43.6 & 44 & 56.4 \\
\hline 11 & $\begin{array}{l}\text { Internet } \\
\text { Facility/Network }\end{array}$ & 78 & 100.0 & - & - \\
\hline 12 & Ilearn & 9 & 11.5 & 69 & 88.5 \\
\hline 13 & Ipad & 69 & 88.5 & 9 & 11.5 \\
\hline 14 & Laptop Computer & 78 & 100.0 & - & - \\
\hline 15 & Local Area Network & 78 & 100.0 & - & - \\
\hline 16 & Megaphone & 78 & 100.0 & - & - \\
\hline 17 & Memory Card & 78 & 100.0 & - & - \\
\hline 18 & Modem & 73 & 93.6 & 5 & 6.4 \\
\hline 19 & Phone & 78 & 100.0 & - & - \\
\hline 20 & Photocopier Machine & 78 & 100.0 & - & - \\
\hline 21 & Printer & 78 & 100.0 & - & - \\
\hline 22 & Podcasting & 42 & 53.8 & 36 & 46.2 \\
\hline 23 & Power Point Software & 58 & 74.4 & 20 & 25.6 \\
\hline 24 & Projection Screen & 68 & 87.2 & 10 & 12.8 \\
\hline 25 & Projector & 65 & 83.3 & 13 & 16.7 \\
\hline 26 & Radio & 78 & 100.0 & - & - \\
\hline 27 & Respondus /Software & 12 & 15.4 & 66 & 84.6 \\
\hline 28 & Scanners & 78 & 100.0 & - & - \\
\hline 29 & Television & 78 & 100.0 & - & - \\
\hline 30 & Video Conferencing & 38 & 48.7 & 40 & 51.3 \\
\hline 31 & Video Recorder & 76 & 97.4 & 2 & 2.6 \\
\hline 32 & Video Tape & 78 & 100.0 & - & - \\
\hline 33 & Virtual Classroom & 12 & 15.4 & 66 & 84.6 \\
\hline 34 & Virtual Library & 18 & 23.1 & 60 & 76.9 \\
\hline 35 & Voice over Internet & 34 & 43.6 & 44 & 56.4 \\
\hline 36 & WiFi & 77 & 98.7 & 1 & 1.3 \\
\hline
\end{tabular}


Bada, A. A., \& Jita, L. C. E-Learning Facilities for Teaching

Secondary School Physics: Awareness, Availability and Utilization

\section{Research Question 2: What e-learning facilities are available for teaching secondary school} physics?

Table 2. E-learning facilities available for teaching secondary school physics

\begin{tabular}{|c|c|c|c|c|}
\hline $\mathrm{S} / \mathrm{N}$ & e-Learning Facilities & Mean & Std. Dev & Remark \\
\hline 1 & Audio tapes & 1.36 & 0.64 & Not Available \\
\hline 2 & CD writer & 2.47 & 1.11 & Not Available \\
\hline 3 & Desktop Computer & 3.82 & 1.21 & Available \\
\hline 4 & Digital Camera & 2.37 & 1.32 & Not Available \\
\hline 5 & Emails & 2.32 & 1.25 & Not Available \\
\hline 6 & E-book Readers & 2.24 & 1.15 & Not Available \\
\hline 7 & Flash Drive & 2.64 & 1.23 & Available \\
\hline 8 & Flexible Learning Toolbox & 1.49 & 0.64 & Not Available \\
\hline 9 & Hard Disk Drives & 2.21 & 1.11 & Not Available \\
\hline 10 & Interactive White Board & 2.53 & 1.20 & Available \\
\hline 11 & Internet Facility/Network & 1.74 & 1.21 & Not Available \\
\hline 12 & Ilearn & 1.83 & 1.33 & Not Available \\
\hline 13 & Ipad & 1.83 & 1.12 & Not Available \\
\hline 14 & Laptop Computer & 1.78 & 1.06 & Not Available \\
\hline 15 & Local Area Network & 1.53 & 1.09 & Not Available \\
\hline 16 & Megaphone & 1.73 & 1.26 & Not Available \\
\hline 17 & Memory Card & 1.38 & 0.84 & Not Available \\
\hline 18 & Modem & 2.96 & 1.17 & Available \\
\hline 19 & Phone & 2.60 & 1.39 & Available \\
\hline 20 & Photocopier Machine & 2.51 & 1.19 & Available \\
\hline 21 & Printer & 1.71 & 1.04 & Not Available \\
\hline 22 & Podcasting & 1.47 & 0.91 & Not Available \\
\hline 23 & Power Point Software & 1.91 & 1.24 & Not Available \\
\hline 24 & Projection Screen & 2.26 & 1.17 & Not Available \\
\hline 25 & Projector & 1.88 & 0.99 & Not Available \\
\hline 26 & Radio & 1.37 & 0.74 & Not Available \\
\hline 27 & Respondus /Software & 1.41 & 0.65 & Not Available \\
\hline 28 & Scanners & 1.78 & 0.62 & Not Available \\
\hline 29 & Television & 2.09 & 1.13 & Not Available \\
\hline 30 & Video Conferencing & 1.47 & 1.02 & Not Available \\
\hline 31 & Video Recorder & 1.18 & 0.39 & Not Available \\
\hline 32 & Video Tape & 1.59 & 1.04 & Not Available \\
\hline 33 & Virtual Classroom & 1.13 & 0.41 & Not Available \\
\hline 34 & Virtual Library & 1.21 & 0.14 & Not Available \\
\hline 35 & Voice over Internet & 1.67 & 0.38 & Not Available \\
\hline 36 & WiFi & 2.05 & 1.09 & Not Available \\
\hline
\end{tabular}

Decision Rule: Mean value $<2.50=$ Not Available, Mean value $\geq 2.50=$ Available 
Table 2 shows the facilities that are available for use in teaching secondary school physics. Table 2 reveals that only six of these e-learning facilities on the checklist (desktop computers, flash drive, interactive white board, modems, phones, photocopier machines) were available for teaching secondary school physics. This translates to $17.0 \%$ availability of these e-learning facilities while the remaining facilities (83.0\%) were not available for use during the teaching of physics in the sampled secondary schools (Figure 1). The finding of this study aligns with Atsumbe et al (2012) who found out that e-learning facilities are not available in the universities not to talk of secondary schools. The result from this research is also not different from the findings of Aboderin and Kumuyi (2013) because they reported shortage in the availability of elearning facilities that can be used to implement the curriculum in secondary schools in Ondo state, Nigeria. This unavailability or shortage in e-learning can affect the realization of the objectives for teaching physics in the secondary schools. This is because physics is an abstract science that relies greatly on practical for students to understand concepts very well. The use of instructional facilities such as e-learning facilities is crucial to reducing this abstract nature of physics in order to guarantee meaning learning.

Figure 1. Availability of e-learning facilities

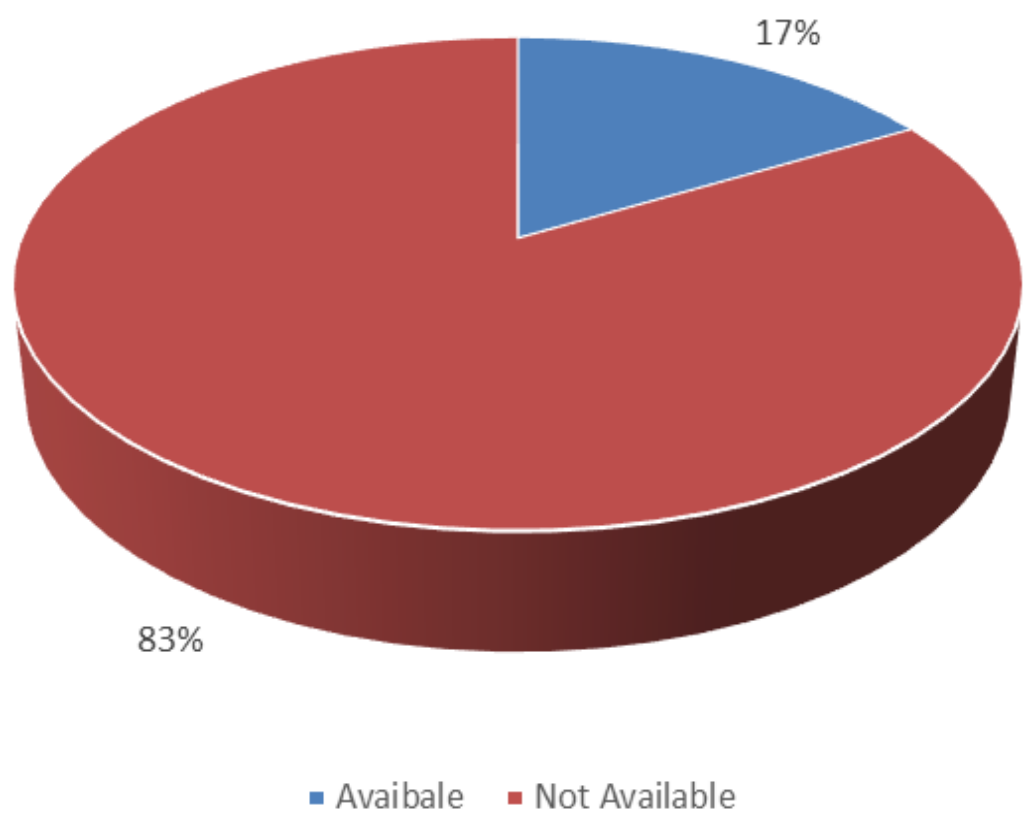


Bada, A. A., \& Jita, L. C. E-Learning Facilities for Teaching

Secondary School Physics: Awareness, Availability and Utilization

Research Question 3: What e-learning facilities are utilized for teaching secondary school physics?

Table 3. Utilization of e-learning facilities for teaching physics

\begin{tabular}{|c|c|c|c|c|}
\hline $\mathrm{S} / \mathrm{N}$ & e-Learning Facilities & Mean & Std. Dev & Remark \\
\hline 1 & Audio tapes & 1.27 & 0.62 & Not Utilized \\
\hline 2 & CD writer & 1.95 & 0.92 & Not Utilized \\
\hline 3 & Desktop Computer & 3.19 & 1.41 & Utilized \\
\hline 4 & Digital Camera & 1.37 & 0.79 & Not Utilized \\
\hline 5 & Emails & 1.96 & 0.95 & Not Utilized \\
\hline 6 & E-book Readers & 1.69 & 1.06 & Not Utilized \\
\hline 7 & Flash Drive & 2.31 & 1.25 & Not Utilized \\
\hline 8 & Flexible Learning Toolbox & 1.24 & 0.49 & Not Utilized \\
\hline 9 & Hard Disk Drives & 1.92 & 0.89 & Not Utilized \\
\hline 10 & Interactive White Board & 2.05 & 1.07 & Not Utilized \\
\hline 11 & Internet Facility/Network & 1.41 & 0.76 & Not Utilized \\
\hline 12 & Ilearn & 1.28 & 0.78 & Not Utilized \\
\hline 13 & Ipad & 1.47 & 0.83 & Not Utilized \\
\hline 14 & Laptop Computer & 1.47 & 0.64 & Not Utilized \\
\hline 15 & Local Area Network & 1.28 & 0.51 & Not Utilized \\
\hline 16 & Megaphone & 1.29 & 0.62 & Not Utilized \\
\hline 17 & Memory Card & 1.18 & 0.38 & Not Utilized \\
\hline 18 & Modem & 2.27 & 1.05 & Not Utilized \\
\hline 19 & Phone & 2.17 & 0.97 & Not Utilized \\
\hline 20 & Photocopier Machine & 2.10 & 0.79 & Not Utilized \\
\hline 21 & Printer & 1.42 & 0.61 & Not Utilized \\
\hline 22 & Podcasting & 1.17 & 0.44 & Not Utilized \\
\hline 23 & Power Point Software & 1.33 & 0.75 & Not Utilized \\
\hline 24 & Projection Screen & 1.71 & 0.76 & Not Utilized \\
\hline 25 & Projector & 1.55 & 0.59 & Not Utilized \\
\hline 26 & Radio & 1.13 & 0.34 & Not Utilized \\
\hline 27 & Respondus /Software & 1.18 & 0.45 & Not Utilized \\
\hline 28 & Scanners & 1.56 & 0.52 & Not Utilized \\
\hline 29 & Television & 1.74 & 0.91 & Not Utilized \\
\hline 30 & Video Conferencing & 1.22 & 0.57 & Not Utilized \\
\hline 31 & Video Recorder & 1.10 & 0.31 & Not Utilized \\
\hline 32 & Video Tape & 1.27 & 0.59 & Not Utilized \\
\hline 33 & Virtual Classroom & 1.00 & 0.00 & Not Utilized \\
\hline 34 & Virtual Library & 1.00 & 0.00 & Not Utilized \\
\hline 35 & Voice over Internet & 1.13 & 0.34 & Not Utilized \\
\hline 36 & WiFi & 1.67 & 0.88 & Not Utilized \\
\hline
\end{tabular}

Decision Rule: Mean value $<2.50=$ Not Utilized, Mean value $\geq 2.50=$ Utilized 
The result on Table 3 shows that only desktop computer was used for teaching physics in the sampled secondary schools. The remaining facilities were not utilized by physics teachers to teach secondary school physics. This accounts for only 3.0\% utilization of e-learning facilities while $97.0 \%$ of the e-learning facilities were not utilized in teaching secondary school physics (Figure 2). Table 3 reveals that all the e-learning facilities (with the exemption of desktop computer) have a mean value less than 2.50 , which is the decision rule for utilization. This finding shows that secondary school physics teachers in Ondo do not utilize e-learning facilities to teach physics. The result of this study agrees with the findings of Akanbi (2020) who also found out that physics teachers in senior secondary schools in llorin did not utilize e-learning facilities when teaching physics. This result is also in agreement with Atsumbe et al (2012) who reported similar case in the tertiary education level. This implies that the inadequate utilization of e-learning still persists despite the development of technology in education, information communication and technology (ICT), and the proliferations of e-learning facilities. The novelty of this study is that it provides empirical evidence for the use of one e-learning facility (desktop computer) in teaching secondary school physics as against the findings of Akanbi (2020) who reported the non-utilization of all the e-learning facilities (desktop computer inclusive). The use of e-learning facilities to teach secondary school physics still requires a lot of improvement because the use of only one e-learning facility would probably give a low significance in terms of utilization. This finding further suggest the low utilization of e-learning facilities in secondary school physics teaching irrespective of school location.

Figure 2. Utilization of e-learning facilities

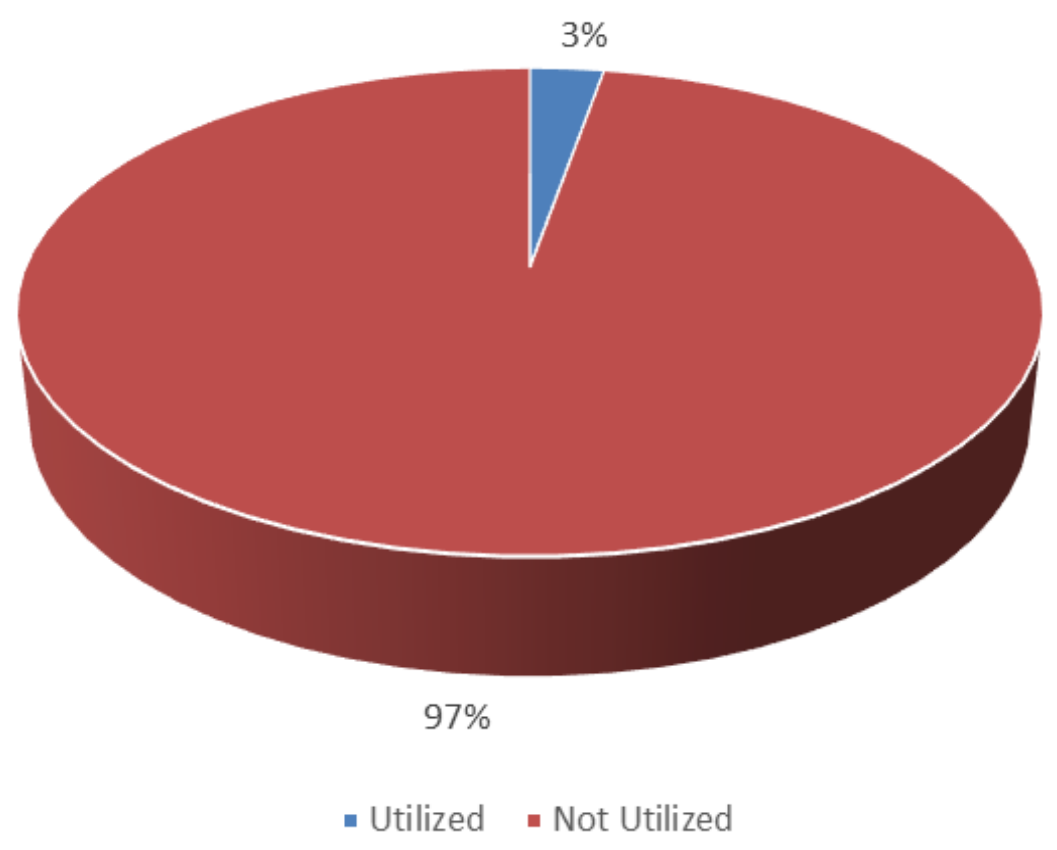




\section{Conclusion}

This study investigated the awareness, availability and utilization of e-learning facilities among secondary school physics teachers in Ondo. Despite the awareness of the e-learning facilities that can be used for teaching physics, the result from this study revealed that many of these facilities are not readily available for teaching physics in the secondary schools. The findings from this study shows that only six facilities were availability for teaching secondary school physics leaving out 30 other facilities that could have been appropriately used for teaching secondary school physics. The results from this study revealed that only one out of these elearning facilities (desktop computer) was utilized by secondary school teachers to teach physics. This finding is considered novel because it provides empirical evidence for the use of desktop computer when teaching secondary school physics because previous studies had reported a total non-utilization of e-learning facilities in physics teaching. The inadequate availability and utilization of these facilities can spell doom for the realization of the objectives for teaching secondary school physics especially in this $21^{\text {st }}$ century. The result of this investigation is an eye opener to the poor integration level of technology into teaching secondary school physics in Ondo, despite the proliferation of technology, its devices and its products. Based on the findings from this study, the following recommendations were considered appropriate.

- Physics teachers should be encouraged to update their knowledge on the relevant elearning facilities that can be used for teaching secondary school physics.

- Physics teachers should be encouraged to adequately utilize the few e-learning facilities that are accessible for teaching senior secondary school physics.

- Government through its agencies and/or school management team should organise inservice training and workshops for physics teachers on the need to be better aware and to utilize the available e-learning facilities for teaching physics.

- More efforts should be made by government through its agency and/or school management team to provide e-learning facilities for teaching secondary school physics.

\section{References}

Aboderin, O. S., \& Kumuyi, G. J. (2013). The problems and prospects of e-learning in curriculum implementation in secondary schools in Ondo State, Nigeria. International Journal of Educational Research and Technology, 4(1), 90-96.

Aggarwal, R., \& Ranganathan, P. (2019). Study designs: Part 2- Descriptive studies. Perspectives in clinical research, 10(1), 34-36. https://doi.org/10.4103/picr.PICR 15418

Akanbi, A. O. (2020). Availability and utilization of e-learning facilities in the teaching of senior school physics in Ilorin, Nigeria. Journal of Education and Learning, 14(3), 331-337. https://dx.doi.org/10.11591/edulearn.v14i3.16342 
Bada, A. A., \& Jita, L. C. E-Learning Facilities for Teaching

Secondary School Physics: Awareness, Availability and Utilization

Akubueze, O. J. (2012). Business educators' utilization and Information and communication technology facilities in tertiary institutions in south-east zone of Nigeria. Nnamdi Azikiwe University, Awka, Nigeria.

Alabi, A. T., Issa, A. O., \& Oyekunle, R. (2012). The use of computer-based testing method for the conduct of examinations at the university of Ilorin. International Journal of Learning and Development, 2(3), 68-80. http://dx.doi.org/10.5296/ijld.v2i3.1775

Atsumbe, B. N., Raymond, E., Enoch, E. B., \& Duhu, P. (2012). Availability and utilization of elearning infrastructures in federal university of technology, Minna. Journal of Education and Practice, 3(13), 56-64.

Eze, S. C., Chinedu-Eze, V. C., \& Bello, A. O. (2018). The utilisation of e-learning facilities in the educational delivery system of Nigeria: A study of M-University. International Journal of Educational Technology in Higher Education, 15-34. https://doi.org/10.1186/s41239-018-0116-z

Eze, S. C., Chinedu-Eze, V. C. A., Okike, C. K., \& Bello, A. O. (2020). Factors influencing the use of e-learning facilities by students in a private higher education institution (HEI) in a developing economy. Humanities and Social Sciences Communications, 7(113), 1-15. https://doi.org/10.1057/s41599-020-00624-6

Fayomi, O. O., Ayo, C. K., Ajayi, L. A., \& Okorie, U. E. (2015). The impacts of e-learning in facilitating academic performance among private secondary schools and tertiary institutions in ota, Ogun State, Nigeria. Covenant University Repository. http://eprints.covenantuniversity.edu.ng/9402/1/ELearning\%20final\%20and\%20updated\%20paper\%20for\%20the\%20INTED\%202015.pdf

Garrison, D. R. (2011). E-learning in the 21st century: A framework for research and practice (2nd ed.). 1-6. Taylor \& Francis.

Halim, A., Wahyuni, A., Malvina, \& Yani, E. (2020). The impact of the use of the internet on the learning outcomes in physics for high school student. Journal of Physics: Conference Series, 1521, 1-7. https://doi.org/10.1088/1742-6596/1521/2/022060

Innocent, W. A., \& Masue, O. S. (2020). Applicability of e-learning in higher learning institutions in Tanzania. International Journal of Education and Development using Information and Communication Technology, 16(2), 242-249.

Ja'ashan, M. M. N. (2020). The challenges and prospects of using e-learning among EFL students in Bisha University. Arab World English Journal, 11(1), 124-137. https://dx.doi.org/10.24093/awej/vol11no1.11

Kopish, M., \& Marques, W. (2020). Leveraging technology to promote global citizenship in teacher education in the United States and Brazil. Research in Social Sciences and Technology, 5(1), 45-69.

Mayadas, A. F, Bourne, J., \& Bacsich, P. (2009). Online education today. Science, 323(5910), 85-89. 
Nassaji, H. (2015). Quantitative and descriptive research: Data type versus data analysis. Language Teaching Research, 19(2), 129-132. https://dx.doi.org/10.1177/1362168815572747

Navarro-Patón, R., Mecías-Calvo, M., Gili-Roig, C., \& Rodríguez-Fernández, J. E. (2020). Disruptive behaviours in physical education classes: A descriptive research in compulsory education. Journal of Human Sport and Exercise, in press. https://doi.org/10.14198/jhse.2022.173.03

Ohlin, C. (2019). Information and communication technology in a global world: Teachers' perceptions of continuing professional development. Research in Social Sciences and Technology, 4(2), 41-57.

Oluwalola, F. K., \& Awodiji, O. A. (2019). Availability and utilization of e-learning facilities for management and business courses in universities in Kwara State, Nigeria. Nigerian Journal of Business Education, 6(2), 346-357.

O'Brien, D. J. (2020). A guide for incorporating e-teaching of physics in a post-COVID world. American Journal of Physics, 89, 403-412.

Ramma, Y., Bholoa, A., Watts, M., \& Nadal, P.S. (2018). Teaching and learning physics using technology: Making a case for the affective domain. Education Inquiry, 9(2), 210-236. https://doi.org/10.1080/20004508.2017.1343606

Rosenberg, M. (2001). E-learning: Strategies for delivering knowledge in digital age. 1-4. McGraw-Hill.

Samba, R. M. O., Achor, E. E., \& Ogbeba, J. A. (2010). Teachers' awareness and utilization of innovative teaching strategies in secondary school science in Benue State, Nigeria. Educational Research, 1(2), 32-38.

Shelly, G., Gunter, G., \& Randolph, G. (2012). Teachers discovering computers: Integrating technology in a connected world (7th ed.). Cengage Learning

Skhephe, M., \& Matashu, M. (2021). The use of technology in accounting classrooms during COVID-19: What do accounting teachers in the Eastern Cape, South Africa, have to say? Research in Social Sciences and Technology, 6(2), 267-278.

https://doi.org/10.46303/ressat.2021.30

Tarman, B., Kilinc, E. \& Aydin, (2019). Barriers to the effective use of technology integration in social studies education, Contemporary Issues in Technology and Teacher Education, 19(4), Retrieved from

https://www.citejournal.org/proofing/barriers-to-the-effective-use-of-technologyintegration-in-social-studies-education/

Zhang, D., Zhao, J. L., Zhou, L., \& Nunamaker, J. F. (2004). Can e-learning replace classroom learning? Communications of the ACM, 47(5), 75-79.

https://doi.org/10.1145/986213.986216 